\title{
Dough flattening machine increase the performance of the onion chips artisan
}

\author{
Anizar $^{1 *}$, Idhar Yahya ${ }^{2}$, Zainul Bahri Torong ${ }^{2}$ \\ ${ }^{1}$ Fakultas Teknik, Universitas Sumatera Utara \\ ${ }^{2}$ Fakultas Ekonomi dan Bisnis, Universitas Sumatera Utara \\ *Email: anizar_usu@usu.ac.id
}

\begin{abstract}
Onion chips are foods made from a dough of flour, water and other ingredients that can be easily found in various places, but are generally made manually. Dough making is an activity that requires the longest time and greatly determines the quality of the resulting onion chips. Crafters need a long time, great effort and complaints of pain in several parts of the body due to this activity. This service activity provides a dough sheeting tool to facilitate the work of craftsmen and reduce activity time. The quality of the onion chips produced is getting better and craftsmen are also free from complaints of muscle pain.
\end{abstract}

Keyword: Dough flaters, ergonomics, onion chips, muscle pain, work posture

\begin{abstract}
Abstrak
Keripik bawang merupakan makanan yang terbuat dari adonan tepung, air dan bahan lainnya yang dapat dengan mudah ditemukan di berbagai tempat, namun umumnya dibuat secara manual. Pembuatan adonan merupakan kegiatan yang membutuhkan waktu paling lama dan sangat menentukan kualitas keripik bawang yang dihasilkan. Perajin membutuhkan waktu yang lama, tenaga yang besar dan keluhan nyeri pada beberapa bagian tubuh akibat kegiatan ini. Kegiatan pengabdian ini memberikan alat pemipih adonan sehingga memudahkan pekerjaan perajin serta mengurangi waktu kegiatan. Kualitas keripik bawang yang dihasilkan semakin baik disamping itu perajin juga terbebas dari keluhan sakit otot.
\end{abstract}

Kata Kunci: Alat pemipih adonan, ergonomi, keripik bawang, nyeri otot, postur kerja

\section{PENDAhULUAN}

Usaha kecil menjadi tempat bagi masyarakat untuk bekerja dan menyambung hidup dimana salah satunya adalah usaha pembuatan keripik bawang. Namun usaha kecil tersebut umumnya masih membutuhkan dukungan berupa akses terhadap teknologi dan informasi, pengembangan sumberdaya manusia dan pemasarannya (Lubis, 2016). Perkembangannya di masa mendatang akan meningkatkan kesejahteraan masyarakat luas (Putra, 2016). Kegiatan pembuatan keripik bawang dimulai dari menyiapkan tepung terigu dan bahan lainnya, mengadon, memipihkan lembaran adonan, memotong, menggoreng hingga mengemas keripik bawang. Proses pengolahan keripik bawang pada umumnya dilakukan secara manual mulai dari proses pencampuran adonan hingga proses pengemasan keripik bawang dilakukan dengan bantuan lilin.

Perajin keripik bawang menghadapi permasalahan terkait fasilitas kerja yang sangat sederhana serta ruang kerja yang sangat sempit sehingga tidak layak sebagai dapur produksi makanan. Perajin keripik bawang memanfaatkan bagian belakang rumah yang tidak dipergunakan sebagai dapur produksi. Hal tersebut menyebabkan dapur produksi beserta fasilitas kerja tidak layak sebagai tempat untuk menghasilkan makanan dengan kriteria memenuhi persyaratan higienis. Kondisi awal dapur produksi pembuatan keripik bawang sebagaimana tertera pada Gambar 1.1. 

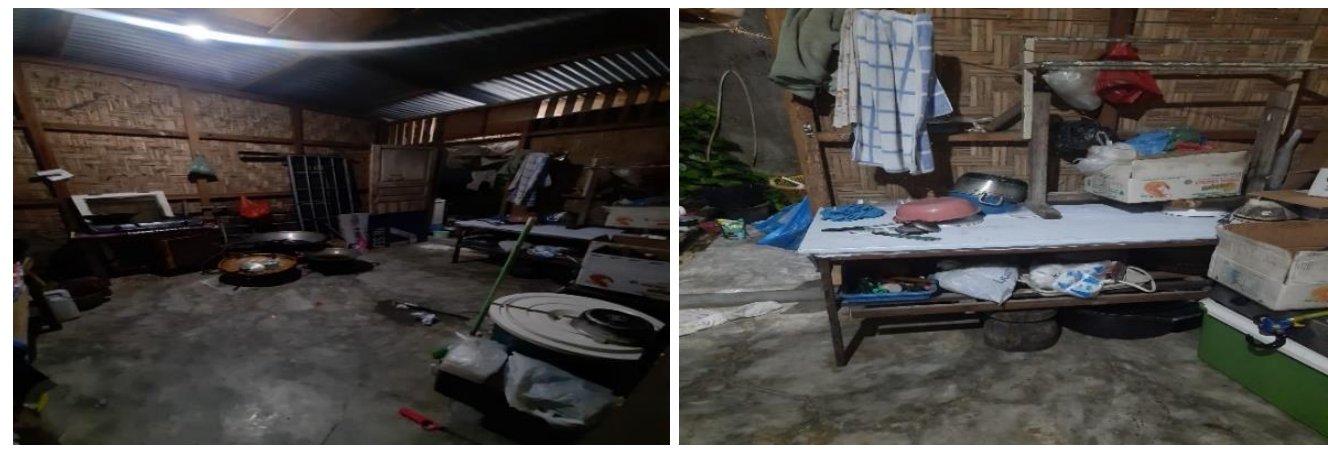

Gambar 1.1. Kondisi dapur produksi keripik bawang

Perajin keripik bawang menggunakan fasilitas yang sangat sederhana dan memanfaatkan peralatan yang ada dirumah. Adonan keripik bawang yang telah dipipihkan menjadi lembaran-lembaran adonan harus ditempatkan pada suatu tempat tertentu agar tidak lengket satu sama lain. Perajin memutuskan menggunakan jemuran handuk demikian juga proses pemotongan lembaran adonan tersebut menggunakan meja sederhana sebagaimana dapat dilihat pada Gambar 1.2.
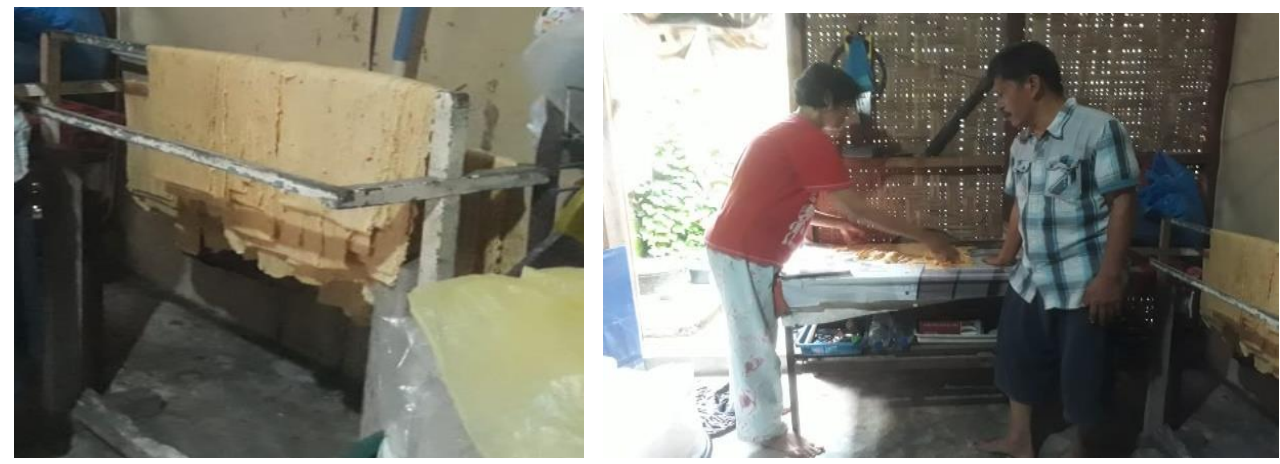

Gambar 1.2. Fasilitas kerja dan proses pemotongan keripik bawang

Perajin melakukan proses penggorengan keripik bawang dan menggunakan wadah plastik serta kantongan plastik untuk menampung keripik bawang sebagaimana ditampilkan pada Gambar 1.3. Penggunaan wadah plastik untuk menampung makanan panas sangat berbahaya bagi kesehatan disebabkan sifat karsinogenik pada plastik jika terkena panas. Penggunaan wadah higienis merupakan syarat mutlak untuk makanan sebagaimana Peraturan Menteri Kesehatan Republik Indonesia No. 1096/Menkes /PER/VI/2011 tentang higiene sanitasi.
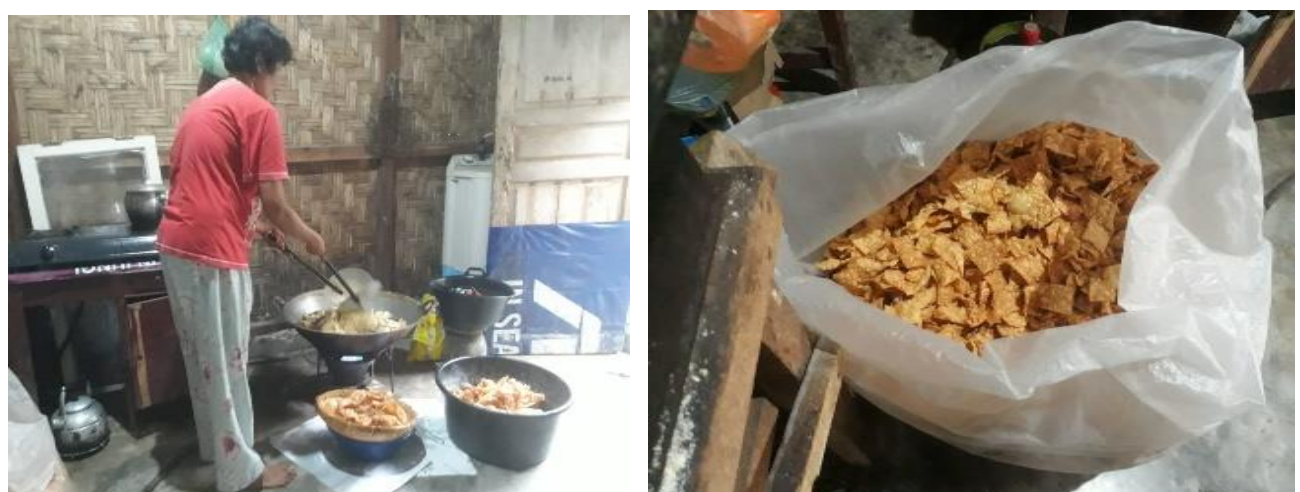

Gambar 1.3. Kegiatan penggorengan keripik bawang dan wadah plastik 


\section{METODE PELAKSANAAN}

Kegiatan pengabdian pada masyarakat ini dilakukan pada usaha pembuatan keripik bawang yang berada di desa Tanjung Anom Kecamatan Pancur Batu Kabupaten Deli Serdang. Permasalahan usaha pembuatan keripik bawang tersebut adalah dapur produksi yang tidak layak disebabkan sempit dan mengambil tempat di bagian belakang rumah. Hal tersebut dapat diatasi dengan memindahkan dapur produksi ke bagian depan rumah yang selama ini tidak dipergunakan.

Target dari kegiatan pengabdian ini adalah perluasan dapur produksi dan peningkatan fasilitas produksi yang akan berdampak pada kuantitas produksi dan produktivitas. Fasilitas yang diberikan berupa dandang, kompor gas, tabung gas, alat pemipih adonan, alat penjemur lembaran adonan keripik bawang, lemari display kaca dan hand sealer.

Alat yang diberikan disesuaikan dengan dimensi tubuh perajin sehingga dilakukan pengukuran dimensi tubuh dengan Human Body Martin Instrument. Perbaikan yang dilakukan oleh tim pelaksana kegiatan pengabdian akan berpengaruh terhadap perajin baik dalam hal metoda kerja, postur kerja hingga tata letak tempat kerja (Habibi \& Soury, 2015). Oleh sebab itu maka kegiatan pendampingan oleh tim ahli ergonomi dengan dibantu oleh beberapa asisten mahasiswa pada Core Laboratory Departemen Teknik Industri USU. Pendampingan dilakukan untuk memberikan masukan dan bimbingan serta pelatihan tentang postur kerja yang aman, nyaman, sehat, efisien dan efektif sehingga perajin dapat memahami dan berangsur-angsur melakukan penyesuaian dengan prosedur kerja yang baru.

\section{HASIL DAN PEMBAHASAN}

Tim pengabdian melakukan pemindahan dan perluasan dapur produksi perajin keripik bawang yang diawali dengan pengadaan bahan bangunan mulai dari pasir, batu bata, semen, jelusi, batu koral, besi, pagar sehingga berdiri dapur produksi sebagaimana terdapat di Gambar 3.1dan Gambar 3.2.

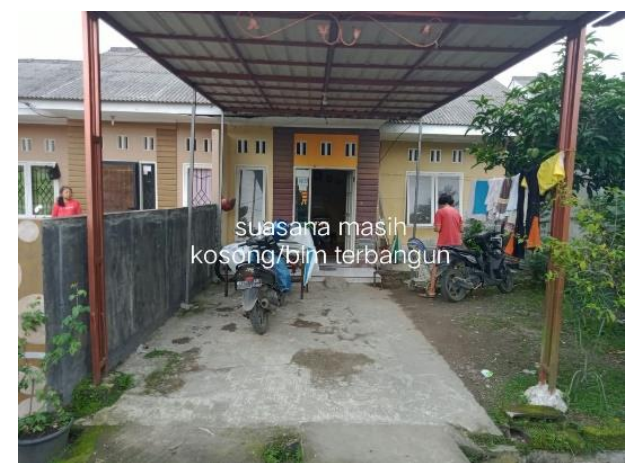

a

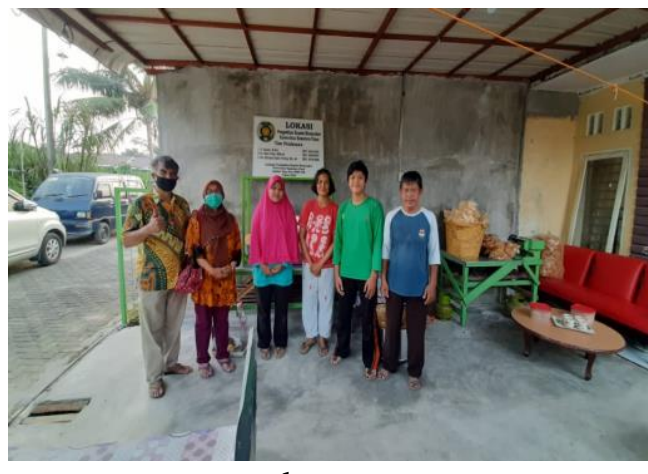

b

Gambar 3.1. (a) lahan kosong di depan rumah (b) dapur produksi setelah renovasi
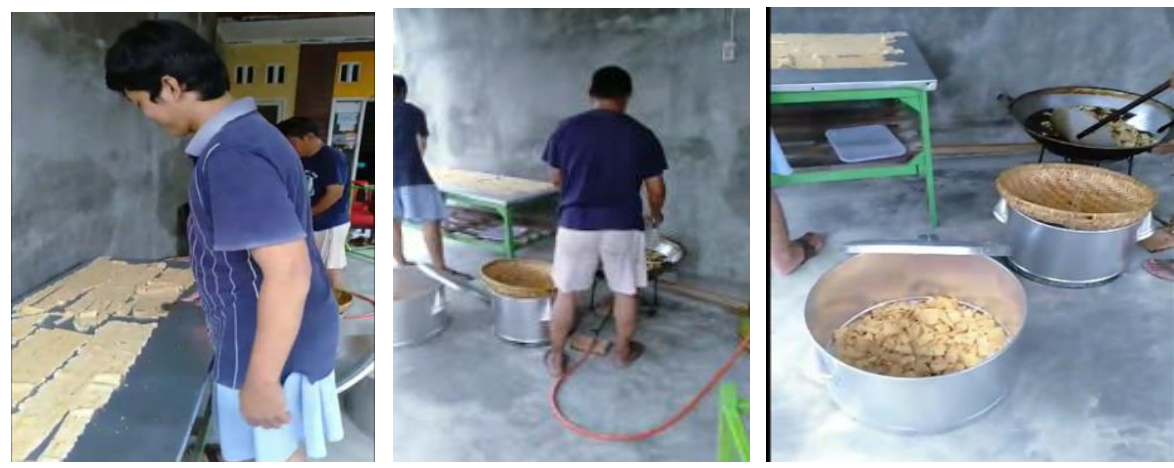

Gambar 3.2. Proses produksi di lokasi yang baru (setelah renovasi) 
Pembuatan keripik bawang dimulai dari menyiapkan tepung terigu dan bahan lainnya, mengadon, memipihkan lembaran adonan, memotong, menggoreng hingga mengemas keripik bawang. Proses pengolahan keripik bawang seluruhnya dilakukan secara manual namun kegiatan pemipihan adonan merupakan proses yang paling lama dan sangat menentukan kualitas keripik bawang. Perajin keripik bawang melakukan kegiatan pemipihan adonan secara manual yaitu memipihkan bulatan adonan dengan cara ditekan hingga pipih secara terus-menerus dengan tangan hingga seluruh adonan habis sebagaimana dapat dilihat pada Gambar 3.3. Perajin membutuhkan waktu hingga 1 menit 7 detik untuk memipihkan satu bulatan adonan berdiameter $13 \mathrm{~cm}$.
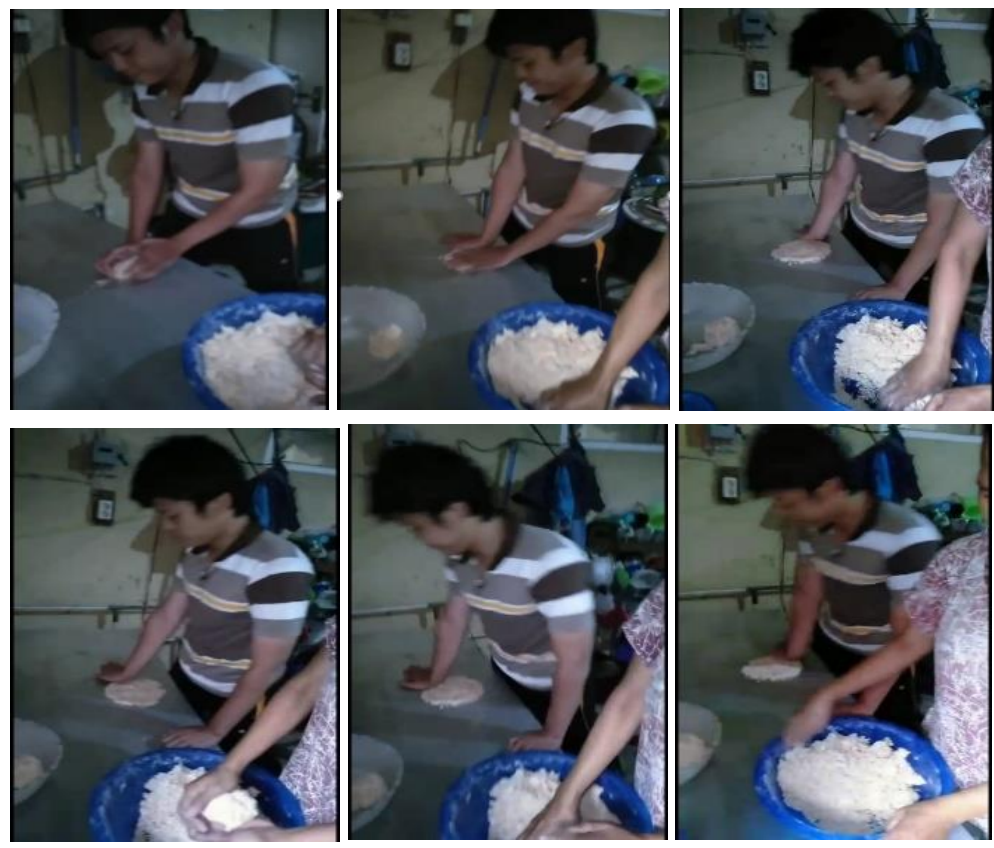

Gambar 3.2. Tahapan proses pemipihan adonan secara manual

Kegiatan tersebut membutuhkan waktu yang lama, tenaga yang besar serta keluhan sakit yang dialami perajin pada beberapa bagian tubuh. Beban kerja fisik secara berulang-ulang (repetitif) membuat otot-otot cepat berkonstraksi sehingga otot mengalami kelelahan dan menimbulkan rasa sakit (Krause \& Scherzer, 2005). Keluhan tersebut mengindikasikan bahwa ada pembebanan yang tidak seimbang pada bagian tubuh perajin. Keluhan inilah yang biasanya disebut sebagai musculoskeletal disorders (MSDs) atau cedera pada sistem muskuloskeletal (Jones, 2015; (Devi T, Purba, \& Lestari, 2017).

Keluhan otot skeletal pada umumnya terjadi karena kontraksi otot yang berlebihan akibat pemberian beban kerja yang terlalu berat dengan durasi pembebanan yang panjang (Dehghan, Aghilinejad, Nassiri-Kashani, Amiri, \& Talebi, 2016). Salah satu faktor yang menyebabkan keluhan muskuloskeletal adalah sikap kerja yang tidak alamiah (Anizar, 2015).

Tim pengabdian memberikan alat pemipih sehingga perajin tidak lagi melakukan proses pemipihan secara manual tersebut. Alat pemipih dilengkapi dengan sebuah dongkrak botol dengan kapasitas beban sebesar 2 ton yang digerakkan secara manual menggunakan tuas. Penggunaan alat pemipih menyebabkan terjadi perubahan metoda kerja pada kegiatan pemipihan adonan (Gambar 3.3). Adonan berbentuk butiran tersebut dikemas dalam kertas menjadi suatu lembaran pipih berukuran $10 \mathrm{~cm}$ x $10 \mathrm{~cm}$ yang kemudian tumpukannya akan diletakkan pada alat pemipih. Proses pemipihan dilakukan sekaligus untuk 10 tumpukan dengan ketinggian sekitar $10 \mathrm{~cm}$. Setelah dipipihkan maka adonan berbentuk butiran tadi sudah menjadi berbentuk lembaran dan siap untuk digiling sehingga menjadi lembaran adonan keripik bawang. 

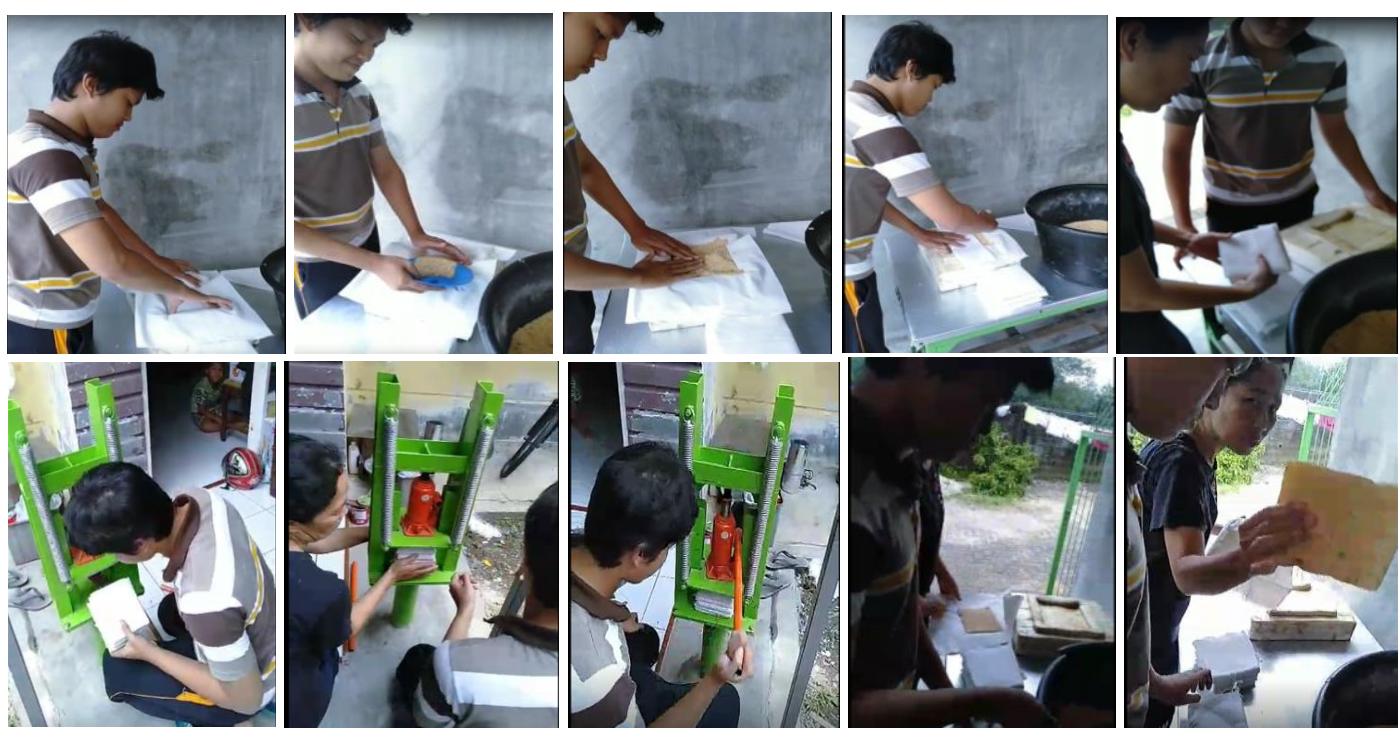

Gambar 3.3. Tahapan proses pemipihan menggunakan alat pemipih adonan

\section{KESIMPULAN (CONCLUSION)}

Pelaksanaan kegiatan pengabdian pada masyarakat yang dilakukan pada usaha pembuatan keripik bawang di Desa Tanjung Anom, Kecamatan Pancur Batu, Kabupaten Deli Serdang berupa penyuluhan tentang metode kerja ergonomis, kesehatan kerja, pembuatan alat diikuti dengan sosialisasi dan pendampingan pemakaian alat pemipih adonan. Kegiatan pemipihan adonan keripik bawang yang selama ini dilakukan secara manual dengan menggunakan tangan berubah menjadi menggunakan alat. Hal tersebut menyebabkan perajin dapat menyelesaikan pekerjaannya dalam waktu lebih singkat disertai dengan tidak adanya lagi keluhan sakit yang selama ini dirasakan

\section{UCAPAN TERIMAKASIH}

Ucapan terima kasih disampaikan kepada Rektor dan Lembaga Pengabdian kepada Masyarakat Universitas Sumatera Utara atas dukungan dana pada kegiatan pengabdian pada masyarakat dengan Program Mono Tahun Reguler Dana Tahun Anggaran 2020 dengan kontrak nomor 287/UN5.2.3.2.1/PPM/2020. Terima kasih juga diucapkan kepada mitra kegiatan pengabdian ini.

\section{DAFTAR PUSTAKA}

Anizar. (2015). Analisis Desain Tojok Sebagai Alat Sortasi TBS Kelapa Sawit di Loading Ramp. Jurnal Teknik Industri, X(3), 149-154.

Dehghan, N., Aghilinejad, M., Nassiri-Kashani, M. H., Amiri, Z., \& Talebi, A. (2016). The effect of a multifaceted ergonomic intervention program on reducing musculoskeletal disorders in dentists. Medical Journal of the Islamic Republic of Iran, 30(1).

Devi T, T., Purba, I. G., \& Lestari, M. (2017). Faktor Risiko Keluhan Musculoskeletal Disorders ( MSDs) Pada Aktivitas Pengangkutan Beras Di PT Buyung Poetra Pangan Pegayut, 8(2), 125-134. 
Anizar dkk. Dough flattening machine increase the performance

Habibi, E., \& Soury, S. (2015). The effect of three ergonomics interventions on body posture and musculoskeletal disorders among stuff of Isfahan Province Gas Company. Journal of Education and Health Promotion, 4(1), 65. https://doi.org/10.4103/2277-9531.162386

Jones, D. R. (2015). The Relationship Between Working Conditions and Musculoskeletal/Ergonomic Disorders in a Manufacturing Facility - A Longitudinal Research Study. Procedia Manufacturing, 3(Ahfe), 4480-4484. https://doi.org/10.1016/j.promfg.2015.07.461

Krause, N., \& Scherzer, Ã. T. (2005). Physical workload, work intensification, and prevalence of pain in low wage workers: results from a participatory research project with hotel room cleaners in Las Vegas. Am J Ind Med 2005;48:326-337.CrossRefMedline, 337, 326-337. https://doi.org/10.1002/ajim.20221.

Lubis, T. A. (2016). Pemanfaatan Teknologi Informasi pada Usaha Mikro Kecil dan Menengah di Kota Jambi, 3(3), 163-174.

Putra, A. H. (2016). Peran UMKM dalam Pembangunan dan Kesejahteraan Masyarakat Kabupaten Blora. 